\title{
Characterization of Green Pigment from Sauropus androgynus Shoot Cultures
}

\section{Oeke Yunita, Devi Veronica Wijayanto, Aulia Dwi Hapsari, Muji Lestari Wahyu Wilang Sari, and Alfian Hendra Krisnawan}

Pharmaceutical Biology Department, Faculty of Pharmacy, University of Surabaya, Surabaya, Indonesia

Corresponding: Oeke Yunita

Email: oeke@staff.ubaya.ac.id

Submitted : 11-05-2021, Revised : 02-06-2021, Accepted : 22-06-2021

\begin{abstract}
The dark green leaves of Sauropus androgynus (Euphorbiaceae) have various nutritive values and are commonly used for human consumption as food, medicine, and natural dye substance in Southeast Asia. Shoot cultures of this plant were established by adding various concentrations of kinetin (Kn) and benzyl adenine (BA) using nodal explants. The best results were recorded when $\mathrm{Kn} 0.1 \mathrm{mg} / \mathrm{L}$ was used with $B A 1 \mathrm{mg} / \mathrm{L}\left(B A_{1} K n_{0.1}\right)$. Spectrophotometric analysis showed two peaks of green pigment in shoot cultures, A pigment $\left(\lambda_{\max }=663.6-663.8 \mathrm{~nm}\right.$, absorbance 0.1111$)$ and B pigment $\left(\lambda_{\max }=611.3-613.9 \mathrm{~nm}, \mathrm{ab}\right.$ sorbance 0.0390). Thin Layer Chromatography (TLC) analysis showed two green spots (Rf $Y=0.31$ and $R f Z$ $=0.25$ ) of shoot cultures on medium supplemented with $B A_{1} K n_{0.1}$ for 10 days. Pigment profiles of shoot cultures were similar to their corresponding mother plants. Random Amplified Polymorphic DNA (RAPD) was used as a preliminary technique to evaluate the genetic similarity of the shoot cultures and their corresponding mother plants. It showed four similar DNA banding patterns to their leaves, ranging from 271-765 $\mathrm{bp}$.

Keywords: green pigment; RAPD; Sauropus androgynus; shoot cultures; Spectrophotometry; Thin Layer Chromatography
\end{abstract}




\section{Introduction}

Sauropus androgynus (L.) Merr. (katuk) is a Southeast Asian indigenous plant widely cultivated for traditional medicinal purposes. The dark green leaves are effective for increasing human breast milk production and their leaves have the potential to become an antioxidant agent [1]. Green leafy plants have nutritive value and contain a high amount of vitamins, phyto-steroid, and phenolic compounds [1,2,3].

The leaves of $S$. androgynus are typically 2-6 $\mathrm{cm}$ long and $1.5-3 \mathrm{~cm}$ wide, the top and bottom of the leaves are dark green and lighter green, respectively. The leaf anatomy of these leaves shows epidermis, equal region of palisade, and spongy tissues with a dense amount of chlorophyll [4]. These leaves have total chlorophyll content of $1.658 \mathrm{mg} / \mathrm{g}$ leaf samples [5].

The antioxidant activity of chlorophyll from $S$. androgynus leaves have potential in the treatment of haemolytic anemia on female mice induced sodium nitrite [6]. Rajalakshmi and Banu[7] also reported a novel visible-light photodetector based on chlorophyll from S. androgynus-modified ZnO nanoparticles.

Fresh dark green leaves of $S$. androgynus from several different areas of East Java, Indonesia, showed different metabolic profiles and DNA banding patterns [8,9]. Rajalakshmi and Banu [10] also found that the concentration of chlorophyll may vary according to the different regions of plant habitat. It is desirable to develop plant tissue culture techniques to assist future studies on the production of chlorophyll to its propagation and genetic improvement. Since it was observed, that production is generally higher in differentiated plant tissues, i.e. shoots in medium because such cultures produced similar patterns of secondary metabolites as mother plants. Shoot cultures are relatively more stable in the production of secondary metabolites than cultures of undifferentiated cells, such as callus or suspension cultures [11,12,13].
S. androgynus shoot cultures had been cultivated in Murashige and Skoog's (MS) medium or Phillips and Collins (L2) medium supplemented with various concentrations of plant growth regulators, i.e. benzyl adenine (BA), kinetin (Kn), indole-3-acetic acid (IAA), 1-naphthalene acetic acid (NAA), 2,4-dichlorophenoxy acetic acid (2,4D), and indole-3-butyric acid (IBA) along with gibberellic acid (GA3) $[11,14,15]$. Eganathan \& Parida [14] showed maximum number of shoots and shoot length was observed on the MS medium containing $1.0 \mathrm{mg} / \mathrm{L} \mathrm{BA}$ and $0.1 \mathrm{mg} / \mathrm{L} \mathrm{Kn}$ after $25 \mathrm{~d}$. Frequent subculture of shoots did not show any morphological variation.

Our previous work used plant tissue culture techniques for obtaining similar green pigment profiles in the cultures with the profiles in the mother plants. Previous study of our work yielded green pigmented callus culture from $S$. androgynus leaves explants initiated on MS medium supplemented with $1 \mathrm{mg} / \mathrm{L} \mathrm{NAA}$ and $0.5 \mathrm{mg} / \mathrm{L}$ BA. The callus induced on this medium was friable and green in color but the yield of green pigment was much lower than in the mother plants [16].

In order to increase green pigment yield in $S$. androgynus cultures before scaling up production of green pigment, this research used plant tissue culture techniques in vitro, by initiating shoot cultures formation from $S$. androgynus nodal explants cultivated in a medium supplemented with various concentrations of $\mathrm{Kn}$ and BA. The parameters examined were the growth index and green pigment profiles analyzed with spectrophotometry and thin layer chromatography (TLC), and genetic similarity of the shoot cultures and their corresponding mother plants evaluated by Random Amplified Polymorphic DNA (RAPD) method on internal transcribed spacer (ITS) regions.

This is the first report for the characterization of green pigment from $S$. androgynus shoot cultures. This tissue culture technique was supported by a molecular approach such as DNA 
fingerprinting to characterize genotype of $S$. androgynus shoot cultures.

\section{Materials and method}

\subsection{Sample preparation}

Young shoots and leaves were obtained from juvenile plants of S. androgynus grown at a private garden in Gunung Anyar, East Surabaya, Indonesia ( $7^{\circ} 14^{\prime} 57^{\prime \prime}$ South, $112^{\circ} 45^{\prime} 3^{\prime \prime}$ East). Tender nodes were extracted as explants by cutting off the petioles of the young branches along within the leaves. All the samples were authenticated by the Center of Information and Development of Traditional Medicine (PIPOT), Faculty of Pharmacy, University of Surabaya, East Java, Indonesia. The leaves were light green, growing up to 3 leaves of shoots in branches, $1.5-3.5 \mathrm{~cm}$ length, $0.5-1.5 \mathrm{~cm}$ wide, had a smooth texture and they did not curl up. The nodal explants were green and had a smooth texture.

\subsection{Culture medium}

Murashige and Skoog (MS) medium was prepared and prior to addition of agar, the $\mathrm{pH}$ was adjusted to 5.8. The medium was supplemented with various concentrations of plant growth regulator, $\mathrm{Kn}$, and $\mathrm{BA}$ with three combinations such as $0.1 \mathrm{mg} / \mathrm{L} \mathrm{BA}$ and $0.01 \mathrm{mg} / \mathrm{L} \mathrm{Kn}\left(\mathrm{BA}_{0.1} \mathrm{Kn}_{0.01}\right.$; M1), $0.5 \mathrm{mg} / \mathrm{L} \mathrm{BA}$ and $0.05 \mathrm{mg} / \mathrm{L} \mathrm{Kn} \mathrm{(BA} \mathrm{BN}_{0.5} \mathrm{Kn}_{0.05}$; M2), $1 \mathrm{mg} / \mathrm{L} \mathrm{BA}$ and $0.1 \mathrm{mg} / \mathrm{L} \mathrm{Kn}\left(\mathrm{BA}_{1} \mathrm{Kn}_{0.1}\right.$; M3).

\subsection{Initiation and cultivation of shoot cultures}

The nodes were first washed with running water without detergent for 1 hour, then followed by disinfecting with ethanol $(70 \% \mathrm{v} / \mathrm{v})$ and rinsing with sterile distilled water. The nodes in sterile distilled water were transferred to a laminar airflow cabinet and then surface disinfected with $1.75 \%$ of sodium hypochlorite for 3 minutes, then followed by rinsing three times with sterile distilled water.

Nodal explants were sectioned into square size $\left(\sim 1 \mathrm{~cm}^{2}\right)$ and cultured in MS medium with different concentrations of BA and $\mathrm{Kn}$. All cultures were maintained to develop shoots in a culture room at $25 \pm 2^{\circ} \mathrm{C}$, humidity $45-55 \%$, and under 8 watts $/ \mathrm{m}^{2}$ light intensity. The mean shoot height, shoot width and mean Growth Index based on fresh weight were recorded during the cultivation. The means comparison and statistical analysis were done using SPSS 16.0 software whereby the effects of plant growth regulator treatments on shoot induction were analyzed utilizing paired samples t-test at $95 \%$ confidence interval.

\subsection{Green pigment extraction and analysis}

S. androgynus leaves and shoot cultures were stored at $-80^{\circ} \mathrm{C}$ before extraction. The samples were ground gently with chilled mortar and pestle since the pigments are heat sensitive and weighed out to $200 \mathrm{mg}$ each in a test tube and then followed by adding $2 \mathrm{~mL}$ of methanol. The mixture was homogenized for 1 min with a vortex. The mixture was extracted 5 times by ultra-sonication followed by centrifugation for 1 $\mathrm{min}$ at $3000 \mathrm{rpm}$. The filtrate was transferred to a $10 \mathrm{~mL}$ volumetric flask with a filter paper. These clear green-colored supernatants were collected and ready for detection of pigments through absorbance spectra analysis by Shimadzu UV-1800 spectrophotometer. The pigment composition was analyzed by the use of TLC method based on the spot color and retardation factor (Rf) on silica gel 60 F254 TLC plates, with $10 \mathrm{~mL}$ mobile phase, comprised of $70 \%$ hexane and $30 \%$ acetone, from the initial orientation, data not shown. The green pigment was observed under visible light, UV light $254 \mathrm{~nm}$, and $366 \mathrm{~nm}$.

\subsection{DNA banding pattern analysis}

Total DNA was isolated from the leaves and shoot culture samples of $S$. androgynus using NucleoSpin ${ }^{\circledR}$ Plant II, according to the manufacturer's instructions.

The primers used for amplification of the ITS regions were ITS-5 (5'-TAGAGGAAGGAGAAGTCGTAACAA-3') and ITS-4 (5'-CCCGCCTGACCTGGGG TCGC-3')[9]. The amplification profile consisted of $95^{\circ} \mathrm{C}$ for 
2 min, cycled 35 times at $95^{\circ} \mathrm{C}$ for $30 \mathrm{~s}, 57^{\circ} \mathrm{C}$ for $1 \mathrm{~min}$ and $71^{\circ} \mathrm{C}$ for $2 \mathrm{~min}$, with a final extension at $71^{\circ} \mathrm{C}$ for $5 \mathrm{~min}$ in a T100 PCR thermal cycler. The ITS region on DNA was then amplified by the RAPD primers (OPD-11: 5'-AGCGCCATTG-3'). The amplification profile consisted of $94^{\circ} \mathrm{C}$ for $5 \mathrm{~min}$, cycled 30 times at $94^{\circ} \mathrm{C}$ for $1 \mathrm{~min}, 35^{\circ} \mathrm{C}$ for $2 \mathrm{~min}$ and $72^{\circ} \mathrm{C}$ for $1 \mathrm{~min}$, with a final extension at $71^{\circ} \mathrm{C}$ for $5 \mathrm{~min}$ in a T100 PCR thermal cycler. The PCR products were visualized in a $1.5 \%$ agarose gel electrophoresis under ultraviolet light to check the presence of amplified bands, using a gel documentation system.

\section{Results and discussion}

The utilization of plant shoot cultures for the production of natural compounds has gained increasing attention over the past decades. Chlorophyll, as photosensitive light-harvesting pigment, is one of the best candidates of the natural compounds for several biological activities. Chlorophylls could act as an important antioxidant found in foods to prevent oxidative DNA damage and lipid peroxidation [17]. The dark green leaves of $S$. androgynus showed attenuation of cyclooxygenase and induced nitric oxide synthase and antioxidant properties [18]. It also provides a rich source of chlorophyll which possesses antioxidant potentials to protect against toxicities induced by sodium nitrate [10] and the anti-anemia effect on female mice induced sodium nitrite [6].

The production of chlorophyll in the plant could be influenced by an interaction of environmental factors with biochemical, physiological, and genetic characteristics of plant, such as the influence of environmental factors on chlorophyll production by Festuca arundinacea [20] and Salvia chamelaeagnea (Lamiaceae) [21]. Plant cell and tissue culture strategies are an attractive alternative to the use of whole plants for the production of pigments and have been the subject of extended research in the last decades. The ability to control both physical and chemical conditions allows the establishment of methodologies that result in increased production of plant metabolites [22]. Therefore, the present study investigates the effects of various concentrations of the plant growth regulator on shoot cultures induction from nodal explants for obtaining green pigment which is similar to corresponding mother plants.

Different concentrations of growth regulators, $\mathrm{Kn}$ and BA were tested in order to obtain the best shoot formation. Initiation of shoots was observed on the medium containing several concentrations of Kn and BA studied adapted from Eganathan \& Parida [14]. Shoot cultures cultivated in various media, such as $\mathrm{BA}_{0.1} \mathrm{Kn}_{0.01}(\mathrm{M} 1), \mathrm{BA}_{0.5} \mathrm{Kn}_{0.05}$ (M2) and $\mathrm{BA}_{1} \mathrm{Kn}_{0.1}$ (M3) could stimulate the production of green pigment after 5 days of culture. The degree of shoot formation was found to be the highest if nodal explants were cultivated in $\mathrm{BA}_{1} \mathrm{Kn}_{0.1}$ medium (M3), while the production of green shoot cultures was maintained until 10 days of culture. Growth of shoot cultures on a fresh weight basis (Figure 1 and 2) was best promoted by $\mathrm{BA}_{1} \mathrm{Kn}_{0.1}$ (M3). Similar reports were showed by Eganathan and Parida [14] while shoot induction was observed in $1.0 \mathrm{mg} / \mathrm{L} \mathrm{BA}$ and $0.1 \mathrm{mg} / \mathrm{L} \mathrm{Kn}$ and more number of shoots were achieved in shoot induction medium. In contrast, the degree of shoot formed from the nodal explants cultured in another media, M1 \& M2, was evidently lower. Most of the cultures turned brown, while browning in tissue culture indicated the release of phenolic compounds, which are toxic to the cultures by inhibition of the cultures growth $[23,24]$.

Growth of shoot cultures was best promoted by $\mathrm{BA}_{1} \mathrm{Kn}_{0.1}$ medium (M3), while this medium could promote shoots of about $0.100 \mathrm{~cm}$ in height and $0.160 \mathrm{~cm}$ in width after 14 days (Table 1 ). Growth of shoot cultures on fresh weight basis (Figure 2) was best promoted by $\mathrm{BA}_{1} \mathrm{Kn}_{0.1}(\mathrm{M} 3)$. The growth curve of shoot cultures indicated that the growth rate of cells was initially slow during the first 9 days. However, after 10 days (exponential phase) the cultures showed a marked increase in growth 


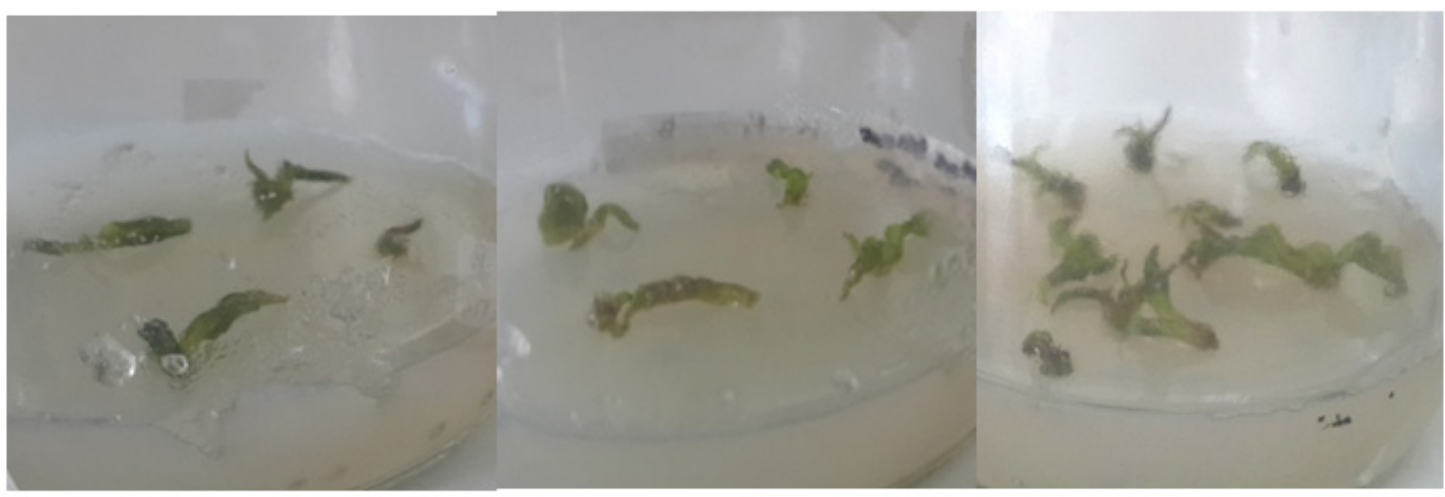

$0.1 \mathrm{~cm}$

(a)

(b)

(c)

Figure 1. Six-week-old shoots cultures induced from nodal explants of Sauropus androgynus on various combinations of Kinetin (Kn) and Benzyl adenine (BA)

(a) Shoots formation on MS + 0.1 mg/L BA and $0.01 \mathrm{mg} / \mathrm{L} \mathrm{Kn}\left(\mathrm{BA}_{0.1} \mathrm{Kn}_{0.01} ; \mathrm{M} 1\right)$ medium

(b) Shoots formation on MS $+0.5 \mathrm{mg} / \mathrm{L} \mathrm{BA}$ and $0.05 \mathrm{mg} / \mathrm{L} \mathrm{Kn}\left(\mathrm{BA}_{0.5} \mathrm{Kn}_{0.05} ; \mathrm{M} 2\right)$ medium

(c) Shoots formation on MS $+1 \mathrm{mg} / \mathrm{L} \mathrm{BA}$ and $0.1 \mathrm{mg} / \mathrm{L} \mathrm{Kn}\left(\mathrm{BA}_{1} \mathrm{Kn}_{0.1} ; \mathrm{M} 3\right)$ medium

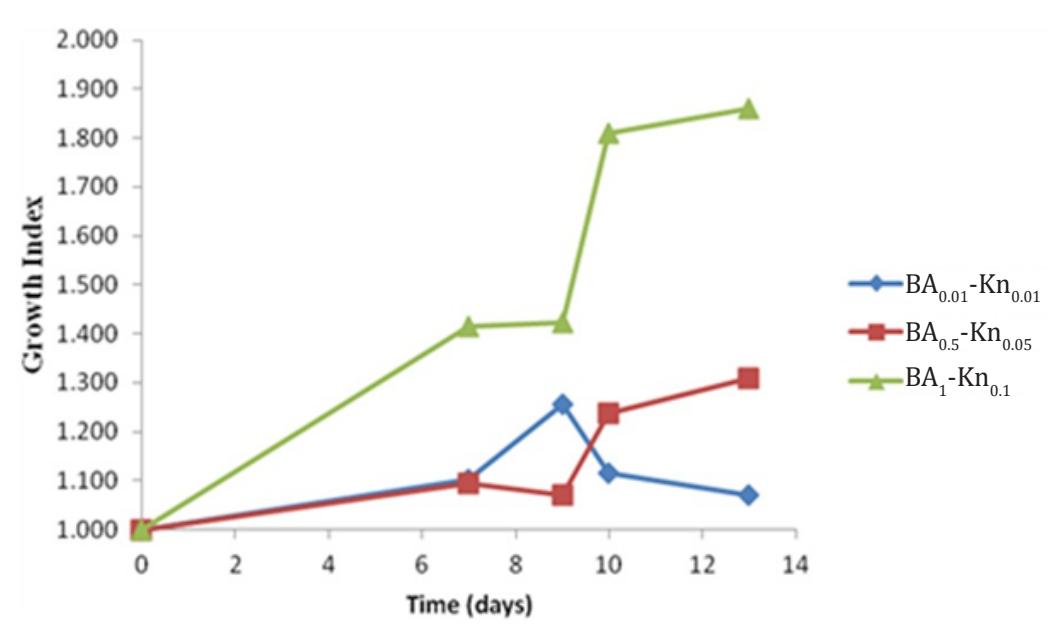

Figure 2. Growth index of shoot cultures of Sauropus androgynus in MS medium supplemented with various combinations of Kinetin (Kn) and Benzyl adenine (BA): $0.1 \mathrm{mg} / \mathrm{L} \mathrm{BA}$ and $0.01 \mathrm{mg} / \mathrm{L} \mathrm{Kn}$ $\left(\mathrm{BA}_{0.1} \mathrm{Kn}_{0.01} ; \mathrm{M} 1\right) ; 0.5 \mathrm{mg} / \mathrm{L} \mathrm{BA}$ and $0.05 \mathrm{mg} / \mathrm{L} \mathrm{Kn}\left(\mathrm{BA}_{0.5} \mathrm{Kn}_{0.05} ; \mathrm{M} 2\right) ; 1 \mathrm{mg} / \mathrm{L} \mathrm{BA}$ and $0.1 \mathrm{mg} / \mathrm{L} \mathrm{Kn}$ $\left(\mathrm{BA}_{1} \mathrm{Kn}_{0.1} ; \mathrm{M} 3\right)$.

Values are mean of 3 replicates from 6-week-old shoot cultures

potential and accumulated a large amount of fresh weight. The rate of growth was stable for 13 days (stationary phase) followed by a gradual reduction in cell density. Mean comparison showed an average growth index of shoots significantly varied with $\mathrm{BA}_{1} \mathrm{Kn}_{0.1}$ (M3) (Table 1). The higher concentration of BA promotes the development of shoot cultures and increases the number of shoots $[25,26]$.

Green pigment estimation was done in the fresh green leaves samples and shoot cultures of $S$. androgynus in $\mathrm{BA}_{1} \mathrm{Kn}_{0.1}$ medium extracted with methanol. The absorbancy readings of green pigment extracts were measured at interval wavelengths between 550 and $750 \mathrm{~nm}$ (Figure 3). Chlorophyll a possesses a green-blue color, and chlorophyll b possesses a green-yellow color, accordingly to Inanç [27] a green leaf absorbs blue light (mostly at $430 \mathrm{~nm}$ ) and red light (mostly at $660 \mathrm{~nm}$ ) regions of the visible spectrum. 
Table 1. Effect of various concentrations of kinetin (Kn) and benzyl adenine (BA) on shoot regeneration from nodal explant of Sauropus androgynus on MS medium

\begin{tabular}{llll}
\hline Hormonal treatment & $\begin{array}{l}\text { Average of shoot } \\
\text { height }(\mathbf{c m}) \\
\text { (Mean } \pm \text { SD) }\end{array}$ & $\begin{array}{l}\text { Average of shoot width } \\
\text { (cm) (Means } \pm \text { SD) }\end{array}$ & $\begin{array}{l}\text { Average of growth index } \\
\text { based on fresh weight } \\
\text { (Mean } \pm \text { SD) }\end{array}$ \\
\hline $\mathrm{BA}_{0.1} \mathrm{Kn}_{0.01}$ & $0.033 \pm 0.0577$ & $0.067 \pm 0.0577$ & $1.069 \pm 0.0900$ \\
$\mathrm{BA}_{0.5} \mathrm{Kn}_{0.05}$ & $0.075 \pm 0.0500$ & $0.150 \pm 0.0577$ & $1.310 \pm 0.2460$ \\
$\mathrm{BA}_{1} \mathrm{Kn}_{0.1}$ & $0.100 \pm 0.0707$ & $0.160 \pm 0.1342$ & $1.890^{*} \pm 0.4500$ \\
\hline
\end{tabular}

Each value represents mean \pm SD from 6-week-old shoot cultures in three repeated experiments *significantly different at $\mathrm{P}<0.05$

$\mathrm{BA}_{0.1} \mathrm{Kn}_{0.01}=0.1 \mathrm{mg} / \mathrm{L} \mathrm{BA}$ and $0.01 \mathrm{mg} / \mathrm{L} \mathrm{Kn}$

$\mathrm{BA}_{0.5} \mathrm{Kn}_{0.05}=0.5 \mathrm{mg} / \mathrm{L} \mathrm{BA}$ and $0.05 \mathrm{mg} / \mathrm{L} \mathrm{Kn}$

$\mathrm{BA}_{1} \mathrm{Kn}_{0.1}=1 \mathrm{mg} / \mathrm{L} \mathrm{BA}$ and $0.1 \mathrm{mg} / \mathrm{L} \mathrm{Kn}$

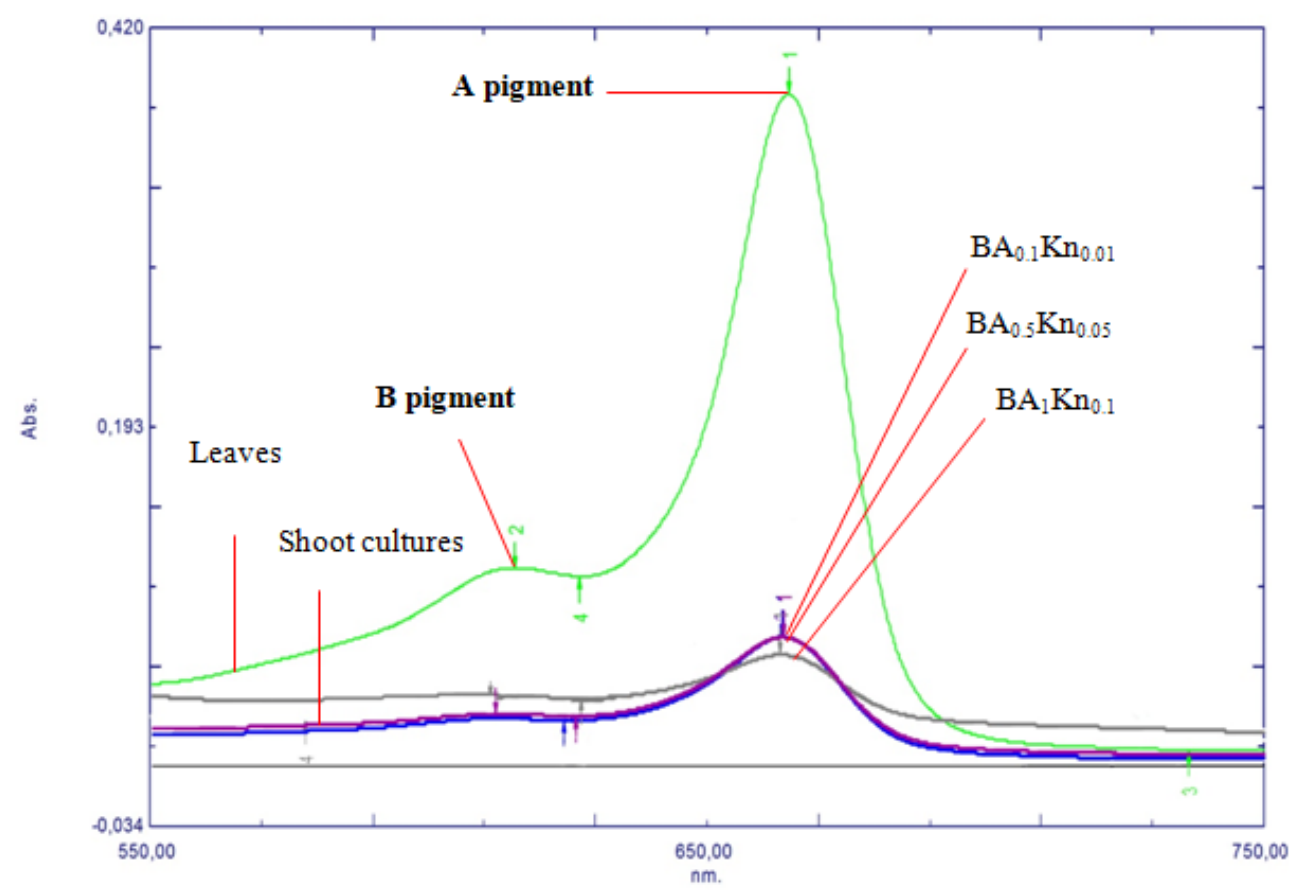

Figure 3. Spectra profiles of green pigments of Sauropus androgynus in leaves and 6-week-old shoot cultures

$$
\begin{aligned}
& \mathrm{BA}_{0.1} \mathrm{Kn}_{0.01}=0.1 \mathrm{mg} / \mathrm{L} \mathrm{BA} \text { and } 0.01 \mathrm{mg} / \mathrm{L} \mathrm{Kn} \\
& \mathrm{BA}_{0.5} \mathrm{Kn}_{0.05}=0.5 \mathrm{mg} / \mathrm{L} \mathrm{BA} \text { and } 0.05 \mathrm{mg} / \mathrm{L} \mathrm{Kn} \\
& \mathrm{BA}_{1} \mathrm{Kn}_{0.1}=1 \mathrm{mg} / \mathrm{L} \mathrm{BA} \text { and } 0.1 \mathrm{mg} / \mathrm{L} \mathrm{Kn}
\end{aligned}
$$

The spectra profile of shoot cultures is similar to the profile of fresh leaves (Figure 3). Each spectra had two main peaks annotated as A pigment (fresh leaves $\lambda=664.5$ to 664.7 $\mathrm{nm}$; shoot cultures $\lambda=663.6$ to $663.8 \mathrm{~nm}$ ) and B pigment (fresh leaves $\lambda=615.2$ to $616.3 \mathrm{~nm}$; shoot cultures $\lambda=611.3$ to $613.9 \mathrm{~nm}$ ). According to Hosikian et al. [28], chlorophyll $a$ absorbs light at wavelengths between 660-665 nm, while chlorophyll $b$ absorbs light at wavelengths between 642-652 $\mathrm{nm}$.

The absorbance value of green pigment in shoot cultures of $S$. androgynus is lower than fresh leaves. The absorbance value of A pigment in both extracts was higher than the value of $B$ pigment (shoot cultures, absorbance value of $\mathrm{A}$ pigment $=0.1111$; $\mathrm{B}$ pigment $=0.0390$ ) . The ratio of chlorophyll $a$ to chlorophyll $b$ in higher plants is approximately $3: 1[29,30]$.

TLC analysis of fresh leaves and shoot cultures 


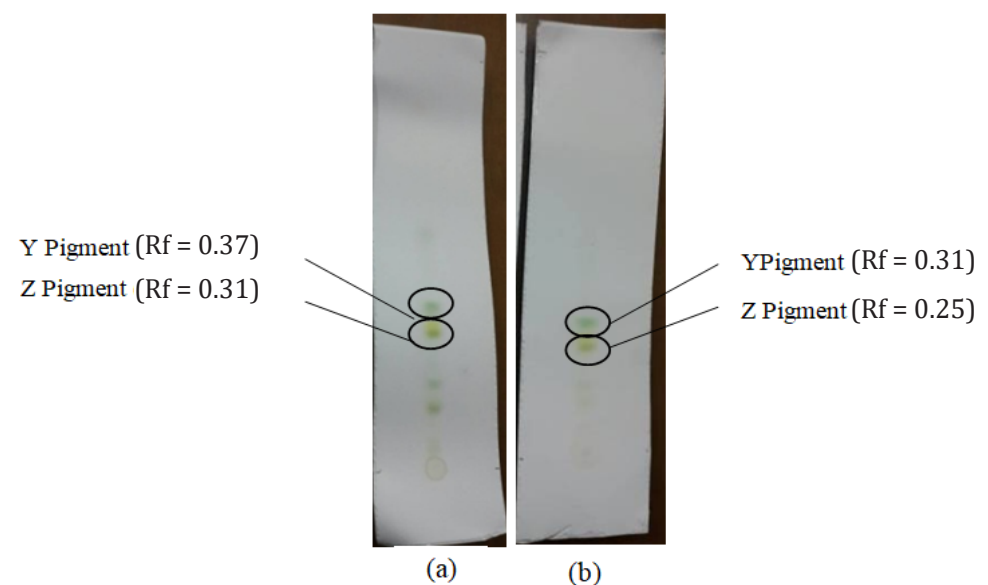

Figure 4. Chromatogram profiles of leaves extract with $\mathrm{RF} Y=0.37, \mathrm{Rf} Z=0.31$ (a); and shoot cultures of Sauropus androgynus with $\mathrm{Rf} Y=0.31, \mathrm{Rf} \mathrm{Z}=0.25$ (b) in visible light

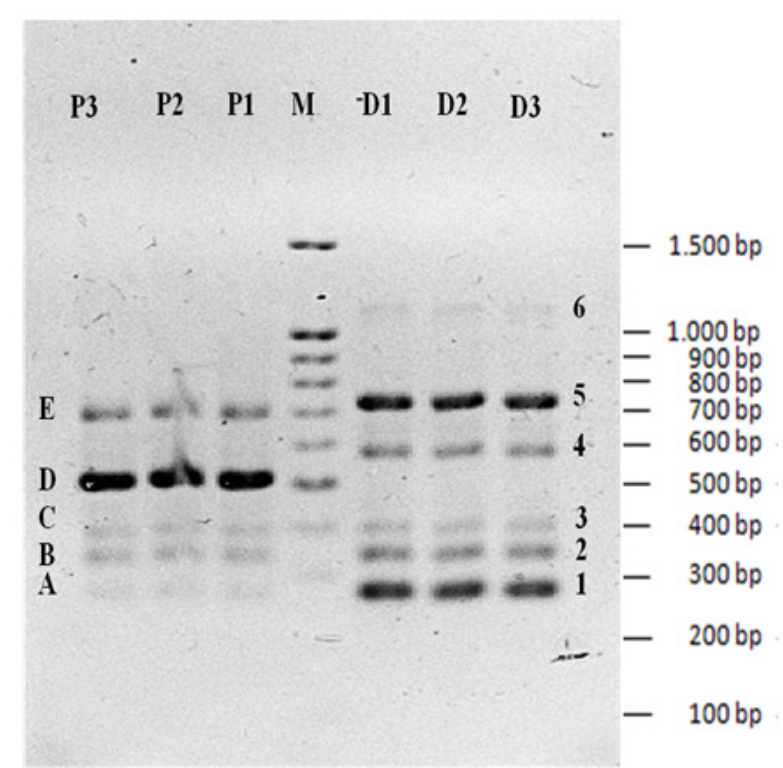

Figure 5. PCR-RAPD on DNA of leaves and shoot cultures of Sauropus androgynus

$\mathrm{M}=$ Marker 100 bp ladder, D1 = leaves 1, D2 = leaves 2, D3 = leaves 3, P1 = shoot culture 1,

$\mathrm{P} 2=$ shoot culture $2, \mathrm{P} 3=$ shoot culture 3

of $S$. androgynus extract (Figure 4), showed two green spots corresponding to $\mathrm{Y}$ pigment and $\mathrm{Z}$ pigment, with $\mathrm{Rf}$ values from fresh leaves were 0.37 and 0.31 , in $\mathrm{Y}$ and $\mathrm{Z}$ pigment respectively, and the Rf values from shoot cultures were 0.31 and 0.25 , in $\mathrm{Y}$ and $\mathrm{Z}$ pigment respectively.

Chromatogram profiles of fresh leaves and shoot cultures showed a similar pattern. Consistently, in a study in Cassia siamea, the chlorophyll in micropropagated plantlets was similar to the mother plants. In these plant tissue cultures, the percentage of chlorophyll content has increased. This may be due to the balanced nutrient level and plant growth regulators in the medium [31].

Rf value of $\mathrm{Y}$ pigment was higher than $\mathrm{Z}$ pigment. This pattern showed that $\mathrm{Y}$ pigment was a slightly more non-polar pigment than $\mathrm{Z}$ pigment. More polar compounds will bound to the polar silica gel and travel short distances on the plate, while non-polar substances will diffuse into the solvent and travel large distances on the plate.

The spectra and chromatogram profiles of fresh leaves and shoot cultures of $S$. androgynus cultivated in $\mathrm{BA}_{1} \mathrm{Kn}_{0.1}$ medium demonstrated that 
pigment profiles of shoot cultures were similar to their corresponding mother plants.

DNA banding patterns of leaves and shoot cultures (Figure 5) showed four similar banding patterns ranging from 271 to $765 \mathrm{bp}$, while the primer used in this study produced polymorphic bands in leaves and shoot cultures. The different DNA band of shoot cultures on approximately 500 bp is assumed as a variation in in vitro cultures. Our previous work showed that callus cultures of S. androgynus had three similar banding patterns to its mother plant and one band that was detected only in fresh leaves [16].

This type of variation can be influenced by alterations in plant growth regulator concentrations and their ratio, in vitro stress due to unnatural conditions, nutritional conditions, and altered diurnal rhythm [33]. Lakshmanan et al. [32] reported that the use of cytokinins, especially the exposure to BA coupled with altered diurnal rhythm and continuous availability of high levels of nutrients have been noted to induce alterations in morphology, but these morphological changes, were found unassociated with the genetic change.

\section{Conclusion}

Shoot cultures of $S$. androgynus cultivated in medium supplemented with $1 \mathrm{mg} / \mathrm{L} \mathrm{BA}$ and 0.1 $\mathrm{mg} / \mathrm{L} \mathrm{Kn}$ yielded two green pigments, $\mathrm{Y}$ and $\mathrm{Z}$, which have similar spectra and chromatogram profiles with their corresponding mother plants. Similar DNA banding patterns of leaves and shoot cultures were showed, ranging from 271-765 bp. In conclusion, the shoot culture of $S$. androgynus can produce green pigments that aresimilar to their corresponding mother plants. This result can be useful for the combination of molecular genetic and chemical analysis that eventually should permit the application of any marker in the selection of high chlorophyll-producing $S$. androgynus shoot cultures.

Further studies on the production of green pigment in shoot cultures of $S$. androgynus may contribute valuable profits in many industries, especially in the pharmaceutical, cosmetics, or food industries.

\section{References}

1. Andarwulan N, Batari R, Sandrasari DA. Flavonoid content and antioxidant activity of vegetables from Indonesia. Food Chemistry. 2010;121:12315.

2. Yu SF, Shun CT, Chen TM. 3-O- $\beta$-D-glucosyl-(16)$\beta$-D-glucosyl kaempferol isolated from Sauropus androgynus reduces body weight gain in Wistar rats. Biological and Pharmaceutical Bulletin. 2006;29:2510-3.

3. Benjapak N, Swatsitang P, Tanpanich S. Determination of antioxidant capacity and nutritive values of pak-wanban (Sauropus androgynus L. Merr.). Khon Kaen University Science Journal. 2008;36:279-89.

4. Elumalai R, Selvaraj R, Arunadevi R, Chidambaram ALA. Foliar anatomical studies of some taxa of Euphorbiaceae. African Journal of Plant Science. 2014;8(6):271-7.

5. Vivek P, Prabhakaran S, Shankar SR. Assessment of nutritional value in selected edible green based on the chlorophyll content in leaves. Research in Plant Biology. 2013;3(5):45-9.

6. Suparmi, Sampurna, Nur ACS, Ednisari AM, Urfani GD, Laila I, Saintika HR. Anti-anemia effect of chlorophyll from katuk (Sauropus androgynus) leaves on female mice induced sodium nitrite. Pharmacognosy Journal. 2016;8(4):375-9.

7. Maddu A, Arjo S, Sofian I. A novel visible-light photodetector based on chlorophyll-modified $\mathrm{ZnO}$ nanoparticles. Photonics Letters of Poland. 2016;8(3):85-7.

8. Yunita O, Rantam FA, Yuwono M. Metabolic Fingerprinting of Sauropus androgynus (L.) Merr. Leaf Extracts. Pharm Sci Asia. 2019;46(2):69-79.

9. Yunita 0, Sulisetiorini. DNA Fingerprinting on ITS Region of Sauropusandrogynus' DNA from East Java, by Random Amplified Polymorphic DNA 
Method. In: Scheer H, Pradhan B, Brotosudarmo THP, editors. International Conference on Natural Sciences. Proceedings; 2011 July 9-11; Batu. Aachen: Shaker Verlag. 2013;251-7.

10. Rajalakshmi K, Banu N. Extraction and Estimation of Chlorophyll from Medicinal Plants. International Journal of Science and Research. 2015;4(11):209-12.

11. Arivalagan U, Alderson PG, Nagarajan A. Effect of growth hormones on callus induction of Sauropus androgynus (sweet shoot). Annals of Biological Research. 2012;3(10):4668-74.

12. Tejavathi DH, Padma S. Regeneration of multiple shoots from the callus cultures of Sauropus androgynus (L.) Merr. Journal of Phytology. 2013;5:10-5.

13. Filová A. Production of secondary metabolites in plant tissue cultures. Research Journal of Agricultural Science. 2014;46(1):236-45.

14. Eganathan P, Parida A. Micropropagation of Sauropus androgynus (L.) Merr. - an important green leafy vegetable. Indian Journal of Biotechnology. 2012;1:235-7.

15. Wee SL. The Effects of Elicitors and Precursor on In Vitro Cultures of Sauropus androgynus for Sustainable Metabolite Production and Antioxidant Capacity Improvement, (Unpublished doctoral dissertation), University of Nottingham, England, United Kingdom; 2015.

16. Yunita O, Wigati BA, Puspitasari MD, Meliyani. Induction Of Green Pigmented Callus Tissue From Sauropus androgynus, Poster Presentation, 2nd Natural Pigments Conference for SouthEast Asia (NP-SEA), July 12-13, 2013, Ma Chung University, Malang; 2013.

17. Hsu CY, Chao PY, Hu SP, Yang CM. The antioxidant and free radical scavenging activities of chlorophylls and pheophytins. Food and Nutrition Sciences, 4. 2013;1-8.

18. Selvi VS, Baskar A. Attenuation of cyclooxygenase and induced nitric oxide synthase and antioxidant properties by Sauropus androgynus (L.) Merr. plant leaves. World Journal of Medical Sciences. 2014;11(3):334-41.

19. Suparmi S, Fasitasari M, Martosupono M,
Mangimbulude JC. Comparisons of curative effects of chlorophyll from Sauropus androgynus (L.) Merr. leaf extract and cu-chlorophyllin on sodium nitrate-induced oxidative stress in rats. Journal of Toxicology. 2016;1-7.

20. Ortolá MP, Daccache A, Knox JW. Modelling irrigation and fertiliser use for chlorophyll production. Grassland Science. 2016;62(2):10211.

21. Lefever $\mathrm{K}$, Laubscher CP, Ndakidemi PA, Nchu F. Effects of $\mathrm{pH}$ and phosphorus concentrations on the chlorophyll responses of Salvia chalmelaeagnea (Lamiaceae) grown in hydroponics, in: Clorophyll. 2017; 79-92, Intechopen.

22. Simões C, Albarello N, deCastro TC, Mansur E. Production of Anthocyanins by Plant Cell and Tissue Culture Strategies, in: Biotechnological Production of Plant Secondary Metabolites. 2012; 67-86.

23. Tabiyeh DT, Bernard F, Shacker H. Investigation of glutathione, salicylic acid and ga3 effects on browning in Pistacia vera shoot tips culture. International Society for Horticultural Science Acta Horticulturae 726. 2006;201-4.

24. Lizawati. Proliferasikalus dan embrio genesis somatik jarak pagar (Jatropha curcas L.) dengan berbagai kombinasi ZPT dan asam amino. Bioplantae. 2012;1(4):256-65.

25. Srinivasan R, Ganapathy S, Karthikeyan K, Chandran C, KulothunganS, Govindasamy C. In vitro propagation of shoot and callus culture of Tectona grandis (L.). Global Journal of Biotechnology and Biochemistry. 2012;7(1):26-9.

26. Wee SL, Alderson PG, Yap WSP. Establishment of planlet regeneration system from nodal, internodal, and leaf explants of Sauropus androgynous (sweet shoot). Asian Journal of Biotechnology. 2015;7(2):46-59.

27. Inanç AL. Chlorophyll: structural properties, health benefits and its occurrence in virgin olive oils. Academic Food Journal, Akademik Gida. 2011;9(2):26-32.

28. Hosikian A, Lim S, Halim R, Danquah MK. Chlorophyll extraction from microalgae: a review 
on the process engineering aspects. International Journal of Chemical Engineering. 2010;1-11.

29. Da Costa JF, Karwur FF, Limantara L. Efek beta karoten dan agregasi klorofil pada foto stabilitas klorofil a dalam pelarut aseton. Jurnal Natur Indonesia. 2009;11(2):115-23.

30. Erge HS, Karadeniz F, Koca N, Soyer Y. Effect of heat treatment on chlorophyll degradation and color loss in green peas. Academic Food Journal, Akademik Gida. 2008;33(5):225-33.

31. Indra M, Manohari JSSD, Muthuchelian K. Biochemical characterization of mother plant and tissue cultured plants of Cassia siamea(Fabaceae). Journal of Biosciences Research. 2011;2(4):25561.

32. Lakshmanan V, Venkataramareddy SR, Neelwarne B. Molecular analysis of genetic stability in long term micropropagated shoots of banana using RAPD and ISSR markers. Electronic Journal of Biotechnology. 2007;10(1):106-13.

33. Modgil M, Mahajan K, Chakrabarti SK, Sharma DR, Sobti RC. Molecular analysis of genetic stability in micropropagated apple rootstock MM106. Scientia Horticulturae. 2005;104(2):151-60. 